\title{
SOME OBSERVATIONS ON THE CLOSURE OF THE ANTERIOR FONTANELLE
}

\author{
BY \\ ROY M. ACHESON and EIRLYS JEFFERSON \\ From the Social Medicine Unit, University of Oxford
}

(RECEIVED FOR PUBLICATION JANUARY 27, 1954)

Early observers (Elsässer, 1843; Friedleben, 1860; Roger, 1859) have claimed that the dimensions of the anterior fontanelle of the human skull increase from the time of birth until about the age of 9 months, and that it is, as a rule, closed at the age of 18 months. Scammon (1923), reviewing this literature, challenged these observations on the grounds that the material studied involved European children of the poorer classes, many of them born prematurely, and many suffering from rickets. He argued that the observations did not necessarily apply to the 'better nourished and more rapidly growing American children', but he did not publish any figures of his own to substantiate his views. Zahorsky (1944) published observations on the date of closure of the anterior fontanelle in American children. Since his subjects were all seen in private practice they probably do not represent an accurate cross-section of the population. He estimated closure of the fontanelle by palpation and tried to correlate the time when it occurred with the type of feed the infants had received in the first four months of life. Aisenson (1950) examined 1,677 New York children in his health clinic and estimated that the mean age of closure of the anterior fontanelle was 13.5 months.

\section{Material}

The children on whom the observations presented in this paper were made were those in the Oxford Child Health Survey. Of the 580 children who attended in the first year (Stewart and Russell, 1952) there were 530 ( 270 boys and 260 girls) with records of fontanelle closure.

Each child was examined clinically at the age of 3 months, and thereafter at three-monthly-intervals during the first year; subsequently the child was seen every six months until the age of 5 . From the age of 6 months radiographic examinations were made at half-yearly intervals; 127 children ( 59 boys and 68 girls) had a lateral radiograph of the skull taken at each half-yearly visit.

\section{Results}

Fontanelle Closure Assessed Radiologically and Clinically. In the group of children who had radiographs taken of the skull, the age at which the anterior fontanelle ceased to be apparent was noted. From the clinical records of the same children the age of closure as judged by palpation was obtained. A comparison of the clinical and radiographic methods has been made (Table 1). The variation

TABLE 1

FONTANELLE CLOSURE ASSESSED CLINICALLY AND RADIOLOGICALLY

\begin{tabular}{|c|c|c|c|c|}
\hline \multirow{3}{*}{$\begin{array}{l}\text { Age in } \\
\text { Years }\end{array}$} & \multicolumn{2}{|c|}{ Boys } & \multicolumn{2}{|c|}{ Girls } \\
\hline & Clinical & Radiological & Clinical & Radiological \\
\hline & $\%$ closed & $\%$ closed & $\%$ closed & $\%$ closed \\
\hline \begin{tabular}{l}
\multicolumn{1}{c}{} \\
1 \\
$1 \frac{1}{2}$ \\
2 \\
$2 \frac{1}{2}$ \\
3
\end{tabular} & $\begin{array}{c}1 \cdot 7 \\
(59) \\
30 \cdot 5 \\
(58) \\
90 \cdot 6 \\
(53) \\
98 \cdot 1 \\
(53) \\
98 \cdot 1 \\
(53) \\
100 \\
(53) \\
100 \\
(53) \\
100 \\
(53) \\
100 \\
(53) \\
100 \\
(53)\end{array}$ & $\begin{array}{c}3 \cdot 6 \\
(56) \\
29 \cdot 6 \\
(54) \\
75 \cdot 5 \\
(49) \\
95 \cdot 8 \\
(48) \\
97.9 \\
(48) \\
100 \\
(49) \\
100 \\
(49) \\
100 \\
(49) \\
100 \\
(49) \\
100 \\
(49)\end{array}$ & $\begin{array}{c}0 \\
(69) \\
18.8 \\
(64) \\
70.3 \\
(64) \\
96.9 \\
(64) \\
98.4 \\
(64) \\
98.4 \\
(64) \\
98.4 \\
(64) \\
98.4 \\
(64) \\
100 \\
(64) \\
100 \\
(64)\end{array}$ & $\begin{array}{c}0 \\
(56) \\
21 \cdot 0 \\
(62) \\
69 \cdot 8 \\
(63) \\
92 \cdot 7 \\
(68) \\
97 \cdot 0 \\
(68) \\
98 \cdot 5 \\
(68) \\
98 \cdot 5 \\
(68) \\
98 \cdot 5 \\
(68) \\
98 \cdot 5 \\
(68) \\
100 \\
(68)\end{array}$ \\
\hline
\end{tabular}

Figures in brackets indicate the number of observations.

in the total number of children examined from one age group to the next is either due to the fact that certain children did not present themselves for examination, or to incompleteness of the records. According to the figures in the table more boys 
than girls had, at given ages, closed fontanelles. The precocity of the boys in this respect is also shown by the mean ages at closure of the fontanelle as judged by clinical methods and radiographs, viz. Table 2. The age of closure of the fontanelle is

TABLE 2

MEAN AGE OF FONTANELLE CLOSURE

\begin{tabular}{ccc|c|c}
\hline \multicolumn{2}{c|}{ Sex } & & Judged Radiologically & Judged Clinically \\
\hline Boys &.. &.. & $17 \cdot 9$ & $16 \cdot 3$ \\
Girls &.. &.. & $19 \cdot 7$ & $18 \cdot 8$ \\
\hline
\end{tabular}

understandably earlier when judged clinically, but the difference is slight. It will be seen that mean age of closure is later for Oxford children than was reported by Aisenson for New York children (1950).

Fontanelle Closure and Skeletal Maturity. Since the differences in radiological and clinical estimates were small, there seemed to be no contra-indication to using the clinical method of assessment for further studies. Thus it was possible to increase the size of the sample studied to include the whole survey group. For these larger numbers no significant correlation was found between the state of the fontanelle and the maturity of the hand and wrist at 1 year. This was true when skeletal maturity was estimated both by the method of Todd (1937) and by that of Acheson (1954).

Fontanelle Closure and the Deciduous Dentition. No correlation was found between fontanelle closure and the number of deciduous teeth which had erupted at any age.

Fontanelle Closure and Height. An attempt was made to correlate the standing height with the age of closure of the fontanelle. Values for height were not available until age $1 \frac{1}{2}$ years. At this age $43 \%$ of the boys and $38 \%$ of the girls were able to stand still long enough for their height to be measured. In order to determine whether 'early' closure occurred in tall or short children, height at $1 \frac{1}{2}$ years was correlated with the state of the fontanelle at 1 year. The correlation for girls between tallness and early fontanelle closure was significant at the $0 \cdot 25 \%$ level. No significant correlation could be found between these two variables for the boys for these ages. In order to exclude the possibility that the relatively small number of children of each sex whose standing height was recorded at $1 \frac{1}{2}$ years could have influenced the result, the standing height at 2 years was compared with the fontanelle at 1 and 2 years. Again a significant correlation was found for the girls (this time at the $3 \%$ level) and not for the boys.

Fontanelle Closure and Skull Circumference. No significant correlation between skull growth, as reflected by maximum circumference, and fontanelle closure was found in either sex. This is in accordance with the observation of Ehrlich (1927).

Fontanelle Closure and Social Class. Consideration of the effect of environment on the age at which the fontanelle closed gave some unlooked-for results. The children were divided into social classes (Registrar General, 1951) (Tables 3 and 4). It will be seen that there is a tendency for

TABLE 3

CLOSURE OF FONTANELLE AND SOCIAL CLASS (BOYS)

\begin{tabular}{|c|c|c|c|c|}
\hline \multirow[b]{2}{*}{$\begin{array}{c}\text { Age at } \\
\text { Examination } \\
\text { (Months) }\end{array}$} & \multicolumn{4}{|c|}{ Percentage Boys with Closed Fontanelle } \\
\hline & All Classes & $\begin{array}{c}\text { Social } \\
\text { Classes } \\
\text { I and II }\end{array}$ & $\begin{array}{c}\text { Social } \\
\text { Class } \\
\text { III }\end{array}$ & $\begin{array}{l}\text { Social } \\
\text { Classes } \\
\text { IV and V }\end{array}$ \\
\hline $\begin{array}{r}6 \\
9 \\
12 \\
18 \\
24 \\
30 \\
36\end{array}$ & $\begin{array}{r}0 \cdot 7 \\
7 \cdot 0 \\
28 \cdot 1 \\
74 \cdot 1 \\
95 \cdot 9 \\
98 \cdot 9 \\
100 \cdot 0\end{array}$ & $\begin{array}{r}0.0 \\
7.9 \\
15.8 \\
71 \cdot 1 \\
94 \cdot 7 \\
100 \cdot 0 \\
100 \cdot 0\end{array}$ & $\begin{array}{r}1 \cdot 1 \\
6 \cdot 4 \\
27 \cdot 3 \\
74 \cdot 9 \\
96 \cdot 3 \\
98 \cdot 9 \\
100 \cdot 0\end{array}$ & $\begin{array}{r}0 \cdot 0 \\
8 \cdot 9 \\
42 \cdot 2 \\
73 \cdot 3 \\
95 \cdot 6 \\
97 \cdot 8 \\
100 \cdot 0\end{array}$ \\
\hline No. of boys & 270 & 38 & 187 & 45 \\
\hline
\end{tabular}

TABLE 4.

CLOSURE OF FONTANELLE AND SOCIAL CLASS (GIRLS)

\begin{tabular}{|c|c|c|c|c|}
\hline \multirow[b]{2}{*}{$\begin{array}{c}\text { Age at } \\
\text { Examination } \\
\text { (Months) }\end{array}$} & \multicolumn{4}{|c|}{ Percentage Girls with Closed Fontanelle } \\
\hline & All Classes & $\begin{array}{l}\text { Social } \\
\text { Classes } \\
\text { I and II }\end{array}$ & $\begin{array}{c}\text { Social } \\
\text { Class } \\
\text { III }\end{array}$ & $\begin{array}{c}\text { Social } \\
\text { Classes } \\
\text { IV and V }\end{array}$ \\
\hline $\begin{array}{r}6 \\
9 \\
12 \\
18 \\
24 \\
30 \\
36\end{array}$ & $\begin{array}{c}0 \cdot 4 \\
6 \cdot 2 \\
25 \cdot 8 \\
72 \cdot 3 \\
91 \cdot 5 \\
98 \cdot 5 \\
99 \cdot 6^{*}\end{array}$ & $\begin{array}{r}0 \cdot 0 \\
4 \cdot 3 \\
21 \cdot 4 \\
66 \cdot 7 \\
90 \cdot 5 \\
100 \cdot 0 \\
100 \cdot 0\end{array}$ & $\begin{array}{c}0 \cdot 6 \\
5 \cdot 8 \\
27 \cdot 5 \\
71 \cdot 3 \\
91 \cdot 2 \\
97 \cdot 7 \\
99 \cdot 4^{*}\end{array}$ & $\begin{array}{r}0 \cdot 0 \\
8 \cdot 5 \\
23 \cdot 4 \\
80.9 \\
93 \cdot 6 \\
100 \cdot 0 \\
100 \cdot 0\end{array}$ \\
\hline No. of girls & 260 & 42 & 171 & 47 \\
\hline
\end{tabular}

* In one girl closure occurred between the ages of 48 and 54 months

children of Social Classes IV and V to close the fontanelles before those of Social Classes I and II. The class difference is significant at the $5 \%$ level for boys aged 1 year but the differences observed in the girls are not significant. It is reported elsewhere (Acheson and Hewitt, 1954) that Oxford boys of Social Classes I and II are taller, and skeletally more mature (Todd) than those of Social Classes IV and $\mathrm{V}$, but the girls show little difference in respect of stature and none in respect of skeletal maturity. 


\section{Discussion}

The closure of the fontanelle must be largely dependent on the growth of the bones bordering on it. This investigation suggests that the development of the membrane bones in the skull is geared differently from that of bones preformed in cartilage. Since it is generally accepted that skeletal maturation in the female occurs more rapidly than in the male (Pryor, 1905, etc.) the earlier closure of the anterior fontanelle in the male is a particularly interesting observation and one which so far as we know had not been noted previously.

The fact that tallness is correlated with early fontanelle closure in girls and not in boys may be a reflection of the fact that the male is more easily upset by an adverse environment than the female (Greulich, 1951; Greulich, Crismon and Turner, 1953; Acheson and Hewitt, 1954). In other words, a fundamental relationship between early fontanelle closure and tallness may have been masked in the male by his greater susceptibility to environmental factors.

The later fontanelle closure in the higher social classes cannot be explained in the light of the present data.

\section{Summary}

The age of closure of the anterior fontanelle has been studied clinically in 530 children of both sexes, and radiographically in 127 of these children.

In this sample the anterior fontanelle closed earlier in the male than in the female. This distinguishes fontanelle closure from skeletal maturation in which the female lead is well known.

Significant statistical correlations have been found between an early fontanelle closure and $(a)$ aboveaverage height in the female, $(b)$ adverse social circumstances in the male.

We wish to acknowledge our indebtedness to Dr. Alice Stewart, and Mr. David Hewitt for advice and criticism.

The Oxford Child Health Survey has been financed by grants from the Nuffield Provincial Hospitals Trust and the Medical Research Council.

\section{BiBLIOGRAPHY}

Acheson, R. M. (1954). In publication.

- and Hewitt, D. (1954). Brit. J. Soc. prev. Med., 8, 59.

Aisenson, M. R. (1950). Pediatrics, 6, 223.

Ehrlich, M. (1927). Arch. Anat. Strasbourg, 7, 427.

Elsässer, C. L. (1843). Der weiche Hinterkopf, Stuttgart. Cited by Scammon (1923)

Friedleben, A. (1860). Jb. Kinderheilk., 3, 61.

Greulich, W. W. (1951). Amer. J. phys. Anthrop., 9, 55.

- Crismon, C. S. and Turner, M. L. (1953). J. Pediat., 43, 121

Pryor, J. W. (1905). Bull. St. Coll. Kentucky, Series 2, No. 1.

Registrar General (1951). Classification of Occupations 1950. H.M.S.O. London.

Roger, H. (1859). Union méd., Paris, Ser. 2, 4, 405

Scammon, R. E. (1923). Abt's Pediatrics, vol. 1, p. 265. Philadelphia.

Stewart, A. M. and Russell, W. T. (1952). Med. Offr., 88, 5. Todd, T. W. (1937). Atlas of Skeletal Maturation-Part I: Hand.

Zahorsky, J. (1944). Arch. Pediat., 61, 259. 